\title{
Conjunctival Carcinoma pN1 TNM Finding v8
}

National Cancer Institute

\section{Source}

National Cancer Institute. Conjunctival Carcinoma pN1 TNM Finding v8. NCI Thesaurus. Code C140550.

Conjunctival carcinoma with regional lymph node metastasis. (from AJCC 8th Ed.) 